\title{
Determination of Cadmium in some cosmetic products
}

\author{
Fuad A.F.Saleh ${ }^{1}$, Ramzi N.A.Saif ${ }^{2}$, Dina M.A.Murshed ${ }^{3}$, Basheer M.A.Abdulmageed ${ }^{4}$. \\ 1, 2-Deparment of Industrial Chemistry -Faculty of Applied Sciences, Taiz University, Taiz, Republic of Yemen. \\ 3- Department of Chemistry -Faculty of Applied Sciences, Taiz University, Taiz, Republic of Yemen. \\ 4- Department of Chemical Engineering -Faculty of Engineering, Hodeidah University, Republic of Yemen.
}

\begin{abstract}
Abs t r a c t
Throughout the ages and times, the need to use everything that reflects women's beauty and helps them maintain their vision and health, and if the need to use the precious materials has been put in place, it is important that they produce the desired results without attention to the harmful chemicals and heavy metals that they contain. Over time, the toxicity of these heavy metals increases in our environment because of their long-term exposure to these pollutants, whether low or high-level in toxicity, animal-prednmost, environment, including air we breathe, water, food, etc. Cosmetics are one of these sources through which humans are exposed to heavy toxic metals. Heavy metals have been estimated in a number of previous studies, and in our study here, we aim to estimate the amount of cadmium metal and study it in various cosmetics such as Lipstick, Eye shadow, Face whitening cream. Two samples were taken from each of the locomoys and cadmium was estimated using the photometer of atomic absorption, one of the samples being expensive and the other low-cost, and purchased from the wholesale markets of Taiz City. Cadmium has been found prominently in these products and the highest rate found in the lowest cost-effective, Eye shadow, that the use of these cosmetic products exposes users to lowconc. heavy metals, which may pose a danger to their health. They are known to be clustered in their biological systems over time, resulting in an imbalance of body and environment. The results found that the low-priced color samples contained a higher concentration of cadmium than the high-price samples in low-priced samples, cadmium concentration was in order of eye shadow > lipstick = face whitening cream. The similar pattern are shown also for higher price product, which are lipstick > face whitening cream > eye shadow.
\end{abstract}

Keyword: Cosmetic, Heavy metals, Toxicity, Cadmium, Atomic Absorption Spectroscopy.

\section{Introduction}

Since the dawn of civilization, the development events, cosmetics have been part of the routine body care and have been a great social group. The past few decades have shown a significant boost in beauty in industries, by producing the different kinds of cosmetics required for skin care, hair, nails, teeth, creams, cosmetics, toning and facial, cosmetics, shampoo, hair oils, oils, hair dyes, hair colors, Scented material, grease sticks, shaving cream, yenna, prawns, and ball. They are made of chemicals that do not leave heavy metals that have a toxic effect on the body.

A cosmetic is a substance or preparation used in contact with various parts of the human body, such as epidermis, hair, nails, lips and external genital organs (external parts) or applied to the teeth Alternatively, mucous membranes of the oral cavity with a view or for the purpose of cleaning, perfuming, protection, changing their outlook, converting body odors and keeping the su faces in good condition $[1,2$, 3].

Heavy metal contamination is one of the important reasons behind the same problem. Heavy metals like lead and cadmium are common contaminant in various cosmetic products $[4,5]$.Cadmium is a deep yellow to orange pigment and mostly present in lipsticks and face powders. 
The use of cadmium in cosmetics products are due to its color property as it has been used as a color pigment in many industries [6] Although many studies have been reported the presence of above metals in cosmetic products especially in lipsticks and nail polish, however data about their presence in soap, talcum powder, shaving cream etc. is scanty. Present study thus planned to see if such cosmetics are contaminated with lead and cadmium. [6] Cadmium is one of the heavy metals that if it were directly subjected to the human body it would decrease the blood pressure [7, 8] The pattern of accumulation of these metals in female body can be altered by some physiological changes. Most of the metals act as endocrine disrupters interfering with the hormonal system $[9,3]$. Both markets faces nonregulations and the unfounded believe that genuine and safer products are found in the bigger and more expensive market like the superstores than in the smaller and less expensive market like the open market. [3]

Hardy et al [10] have analyzed total 23 kohl samples for heavy metal contamination, in results they concluded that lead was found to be the main constituent of almost half the kohl samples examined in this study. Recently heavy metals like lead, cadmium were determined in lipstick using laser induced breakdown spectroscopy where they found the concentrations of lead, cadmium and chromium was beyond their safe maximum permissible limit (MPS) i.e. $0.5 \mathrm{ppm}, 0.5 \mathrm{ppm}$ and $1 \mathrm{ppm}$ respectively [11].Although the presence of cadmium in the samples were in trace amount but the slow release of cadmium with low amount may also cause harmful effects to the human body. The presence of cadmium has also reported in various lipsticks [11] it does not have to be present in abundance in products to produce hypertension. In fact, results from tests showed that it was minor exposure that caused high blood pressure. When cadmium was injected directly into the subject, it caused blood pressure to drop. Therefore, the small amounts are not safe. It targets blood vessel and heart tissue, as well as, the kidneys, lungs and brain, and results in heart disease,
Hypertension, liver damage, suppressed immune system and other nasty symptoms $[12,13]$. The aim of this research was to determine the concentration of a heavy metal in the beauty products in Taiz by identifying the cadmium concentration of Lipstick, Eye shadow and Face whitening cream. This heavy metal is among the most toxic heavy metals and their role in cosmetics.

\section{Experimental Section}

\subsection{Collection of Samples}

Samples from cosmetics stores were collected at the wholesale market in Taiz City. A total of three different beauty products (LP,ES,FW) were taken per product, and in this way 6 samples (2 per LP,ES,FW, respectively) were collected for one beauty product, one of which is expensive and one of which is low price. Information on the test materials and quantities used in this study is summarized in Table 1. Two different brand eyes have been assembled for each of the beauty devices with its own Lipstick, Eye shadow, Face whitening cream.

\subsection{Statistics analysis}

Total tow samples of same product were analyzed for metal estimation and mean value was shown in results.

Table 1 Summarization of test items and their quantity used in the study

\begin{tabular}{|c|c|l|l|c|}
\hline $\begin{array}{c}\text { Sample } \\
\text { No. }\end{array}$ & $\begin{array}{l}\text { Brand } \\
\text { code }\end{array}$ & $\begin{array}{l}\text { Sample } \\
\text { name }\end{array}$ & $\begin{array}{l}\text { Code } \\
\text { name }\end{array}$ & $\begin{array}{l}\text { Number } \\
\text { sample }\end{array}$ \\
\hline 1 & $\begin{array}{c}\text { Lower } \\
\text { price } \\
\text { (L) }\end{array}$ & $\begin{array}{l}\text { Lipstick. } \\
\text { Eye } \\
\text { shadow. } \\
\text { Face } \\
\text { whitening } \\
\text { cream. }\end{array}$ & ES - L & 1 \\
& $\begin{array}{c}\text { Higher } \\
\text { price } \\
\text { (H) }\end{array}$ & $\begin{array}{l}\text { Ey L } \\
\text { Eyadow } \\
\text { Face } \\
\text { whitening } \\
\text { cream. }\end{array}$ & FW - H & 1 \\
\hline 2 & ES - H & 1 \\
\hline
\end{tabular}




\subsection{Preparing the samples:}

\section{This stage is take two steps:}

The first: a. Burning and incineration out of five to one gram of considered sample was placed in a porcelain couple next added $0.5 \mathrm{ml} \mathrm{HNO}_{3}$ then heated all samples for drying. After cooling, the couples were put in the incineration device at $500 \pm 50 \mathrm{C}^{0}$ for $3.5 \mathrm{~h}$ Once more than the samples were cooled again.

After last cooling, $3 \mathrm{ml} \mathrm{HNO}_{3}$ were added to each sample and dried them by using an electrical heater. After that filtered the samples to $25 \mathrm{ml}$ beaker by using paper filter then added distilled water to the final volume. Finally, the concentration of each considered metal was measured by atomic absorption device.

\section{A.b. Procedure}

Twenty-five grams $(25.0 \mathrm{~g})$ of sample were placed in microwave tubes. Accurately added $6 \mathrm{ml}$ of conc. $\mathrm{HNO}_{3}$ and $2 \mathrm{ml}$ of $\mathrm{HF}$ then the tube was put in the microwave instrument, which turned off for cooling after the digestion was finished. Added distilled water at temperature room degree. By filter paper, the solution was filtered to a $50 \mathrm{ml}$ flask and added distilled water to the mark. The resultant solution was then analysis atomic absorption device.

\section{The second:}

Prepare the reference solutions the reference solutions for each metals, which demand computation in cosmetics (lipstick) from standard solution high purity by using Mohr equation:

$$
N \times V=N_{1} \times V_{1}
$$

\section{Where us:}

$\mathrm{N}$ : Normality of standard solution.

V: The taken volume.

$\mathrm{N}_{1}$ : Normality of reference solution.

$\mathrm{V}_{1}$ : The final volume.

By take $10 \mathrm{ml}$ from standard solution to flask $(100 \mathrm{ml})$ and expand the volume to $100 \mathrm{ml}$.

\section{4. used instruments and chemical materials}

\subsubsection{Instruments and tools}

Table 2: Show list of instruments and tools, which used in research.

\begin{tabular}{|l|l|}
\hline Instruments & Tools \\
\hline Balance & Porcelain couple \\
Microwave oven & Pipettes \\
Electric heater & Flasks \\
Atomic absorption & Beakers \\
& Funnels \\
& Tubes \\
& Filter papers \\
\hline
\end{tabular}

\subsubsection{Chemical materials}

Table 3: Show material, which used in research

\begin{tabular}{|c|c|c|c|}
\hline No. & $\begin{array}{l}\text { Name of } \\
\text { material }\end{array}$ & Company & Assay \\
\hline 1 & $\begin{array}{l}\text { Standard Cd } \\
\text { sol. (1000ppm) }\end{array}$ & $\begin{array}{l}\text { Fisher } \\
\text { chemical }\end{array}$ & ------------- \\
\hline 2 & $\mathrm{HNO}_{3}(70 \%)$ & -------------- & --------------- \\
\hline 3 & Distilled water & Commercial & Commercial \\
\hline 4 & $\mathrm{HF}(70 \%)$ & $\begin{array}{l}\text { Sigma- } \\
\text { Aldrich }\end{array}$ & $68-70 \%$ \\
\hline 5 & $\begin{array}{l}\text { Mix }\left(\mathrm{HNO}_{3}+\right. \\
\mathrm{HF}) 3: 1\end{array}$ & -------------- & ------------ \\
\hline 6 & $\mathrm{H}_{2} \mathrm{O}_{2}(35 \%)$ & $\begin{array}{l}\text { Sigma- } \\
\text { Aldrich }\end{array}$ & $\begin{array}{l}34.5- \\
36.0 \%\end{array}$ \\
\hline
\end{tabular}

\section{5. (c) Preparation the solution for each measured metals:}

1- Take beaker $(100 \mathrm{ml})$

2- Add $3 \mathrm{ml}$ of $\mathrm{HNO}_{3}$.

3- Expand the volume to the mark.

4- Shake the mixture to use in the determined of analysis metals. 


\section{(D) Analysis of metals by A.A.S}

Frist start up the Atomic Absorption Spectroscopy (A.A.S) and titrate the sample prepared. Cathode lamp (for each metal) by taken the high absorbance which dene by titrate the atomic spiral key that find on A.A.S toady. Then pass the blank sample and references solution on A.A.S to obtain on the sample prepared. Curve for each metal, which appear the relationship between the concentrated of references solution and absorbance values.

After that: the samples is passing through A.A.S to obtain on absorbance values with concentration ppm the samples passed through A.A.S three time and average was taken. Flow rate of Ar 54.51 min (zinc, cadmium, lead) mercury we use the (No or acetylene)

\subsubsection{Heavy metals quantification}

two metals i.e. lead and cadmium was analyzed through Atomic Absorption Spectroscopy.

\section{Results and discussion}

Cosmetics is one of the most important sources of heavy metals release in the environment. Skin/skin irritation may increase due to heavy metals in cosmetics. Since the toxicity of heavy metals is a problem of environmental pollution, it is necessary to know all possible sources. In this context, we have tested various beauty products for cadmium. Three cosmetics have been taken for study. The three products are priced in low-price and high-price lotions, and the results of cadmium concentration are depicted in different cosmetic products in table 4.

The following table 4: One shows the values of cadmium concentration in the cosmetics studied.

\begin{tabular}{|c|c|c|c|c|c|c|}
\hline \multirow[b]{2}{*}{$\begin{array}{l}\text { Cosmetic } \\
\text { pro. }\end{array}$} & \multicolumn{3}{|c|}{ Low } & \multicolumn{3}{|c|}{ High } \\
\hline & $\begin{array}{l}\text { Mean } \\
\pm S D\end{array}$ & $\begin{array}{c}\text { Media } \\
\mathbf{n}\end{array}$ & $\begin{array}{c}\text { Ran } \\
\text { g }\end{array}$ & $\begin{array}{l}\text { Mean } \\
\pm S D\end{array}$ & $\begin{array}{c}\text { Media } \\
\mathbf{n}\end{array}$ & $\begin{array}{c}\text { Ran } \\
\mathbf{g}\end{array}$ \\
\hline $\begin{array}{l}\text { Lipstick } \\
\text { (LP) }\end{array}$ & $\begin{array}{c}0.10 \pm \\
0.02 \\
\end{array}$ & 0.11 & $\mathbf{0 . 0 3}$ & $\begin{array}{c}0.08 \\
\pm 0.03 \\
\end{array}$ & 0.07 & 0.07 \\
\hline $\begin{array}{l}\text { Eye } \\
\text { shadow } \\
\text { (ES) }\end{array}$ & $\begin{array}{l}0.17 \\
\pm 0.03\end{array}$ & 0.16 & 0.06 & $\begin{array}{l}0.11 \\
\pm 0.02\end{array}$ & 0.11 & 0.02 \\
\hline $\begin{array}{l}\text { Face } \\
\text { whitenin } \\
\text { g cream } \\
\text { (FW) }\end{array}$ & $\begin{array}{l}0.11 \\
\pm 0.00\end{array}$ & 0.11 & 0.00 & $\begin{array}{l}0.08 \\
\pm 0.01\end{array}$ & 0.08 & 0.04 \\
\hline
\end{tabular}

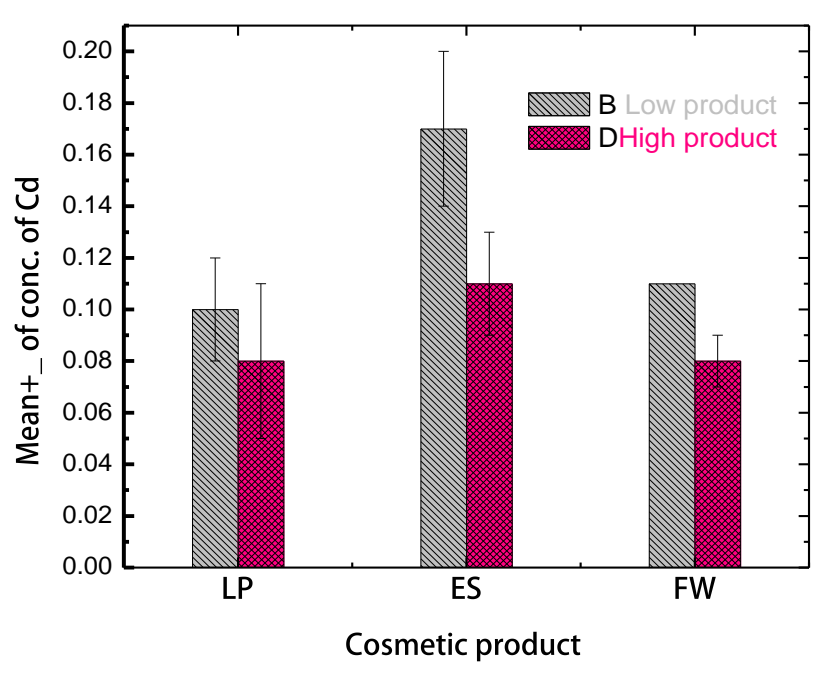

Figure1: Cadmium concentration in cosmetics (microgram/gram).

From Table(4), the mean \pm SD concentration of cadmium in cosmetics sample were ranged from $(0.11 \pm 0.00) \mathrm{mg} \mathrm{kg}^{-1}$ in face whitening cream to $(0.17 \pm 0.03) \mathrm{mg} \mathrm{kg}^{-1}$ in eye shadow. Among the analyzed samples, the highest concentration of cadmium was detected in colored decorative cosmetics products, eye shadow and face whitening cream. While lipstick showed lowest cadmium content. The median concentration of the heavy metal $\mathrm{Cd}$ analyzed in lower price product are in the order of eye shadow > lipstick = face whitening cream. The similar pattern are shown also for higher price product, which are lipstick $>$ face whitening cream > eye shadow. From Table (4), Cd was detected in all samples in both sample groups. However, the concentration level is not exceeded the WHO and NADFC permissible limit which are $5 \mathrm{mg} \cdot \mathrm{kg}^{-1}$.

Comparison between same products with different brand, brand A ( lower price products) showed the higher concentration of cadmium than brand B ( higher price products), (Figure 1). Furthermore, for face whitening cream, lipstick in lower price and eye shadow, face whitening cream in higher price, $\mathrm{T}$ test showed no significant difference statistically between the higher and lower price cosmetics in terms of the concentration of the heavy metal $\mathrm{Cd}$ analyzed $(\mathrm{p}<0.05)$. 


\section{Conclusions}

In this study, cadmium was estimated in various cosmetics from different brands. Based on the results, we concluded that cadmium was one of the most prominent heavy toxic metals in cosmetics; it was above the permissible limit. The continued use of products contaminated by this heavy metal may slow the release of these metals into the human body, indicating the harmful effects they have mentioned earlier. The extensive uses of such products must be avoided.

\section{Recommendations}

1. Systematic monitoring and control of heavy metals and other chemicals used in manufacturing Emphasis should be placed on beauty products that may cause health risks to users. 2- Drafting of regulatory guidelines on heavy metals in cosmetics Carried out by the competent authorities in the field of making beauty products in Yemen 3- To organize public awareness of the adverse effects of excessive use of or Extensive use of beauty products. 4- Enact laws to limit and replace heavy metal content in cosmetics other household products and other items. 5- Withdrawal of products containing large quantities of heavy metals from the markets and non-importation of them again. 6-. Identify ways of safe disposal of products with heavy metals. 7- Strict customs laws for goods suspected of containing heavy metals.

\section{Conflict of interest:}

\section{No conflict of interest.}

\section{References}

[1] Oyedeji, F. O., Hassan, G.O. and Adeleke, B.B. (2011): Hydroquinone and Heavy Metals Levels in Cosmetics Marketed in Nigeria. Trends in Applied Sciences Research. 6; 622-639

[2] Reed, S.I. (2004): Cosmetics and your health. U.S Department of Health and Human Services. http://www.womens health govl/faq/cosmetics- your health.pdf
[3]A.Sani,M.B.Gaya,F.A.Abubakar,determination of some heavy metals in selected cosmetic products sold in Kano metropolis, Nigeria, Toxicology Reports

http://dx.doi.org/10.1016/j.toxrep.2016.11.001

[4]IC Nnorom; JC Igwe; CG Oji-Nnorom. African J. Biotech., 2005, 4, 1133-1138. [5]I Al-Saleh; S Al-Enazi; N Shinwari. Regulat Toxicol. Pharmacol., 2009, 54, 105-113

[6]A.S.Chauhan,R.Bhadauria,A.K.Singh,Sh.S.Lod hi, D.K.Chaturvedi,V.S.Tomar, Determination of Lead and Cadmium in cosmetic products J. Chem. Pharm. Res., 2010, 2(6):92-97

[7]. Alissa EM, Ferns GA. Heavy Metal Poisoning and Cardiovascular Disease. J Toxicol 2011: 21 pages.

[8]H.Naalbandi,M.Saeedi,O.M.Moghanlou, J.Akbari,K.M.Semnani,R.Alizadeh,M.H.E.Zadeh, M.Tajbakhsh5 Evaluation of heavy metal content of some lipsticks in Iran market Pharmaceutical and Biomedical Research Pharm Biomed Res 2016;2(3):31-37DOI: 0.18869/acadpub.pbr.2.3.31

[9] Bergamaschi, L., Izzio, E. R. Giaver I. G., Loppi M. S. and Gallo R. (2007): Comparision between the accumulation capacity of four lichen species transplanted to a urban site. Environ. Pollut., 148, 468-476.

[10] AD Hardy; HH Sutherland; R Vaishnav. $J$. Ethanopharmacol, 2002, 80, 137-145.

[11] MA Gondal; ZS Seddigi; MM Nasr; B Gondal. J. Hazard Mat., 2010, 175, 726-732.

[12] J Godt; F Scheidig; C Grosse-Siestrup; V Esche; P Brandenburg; A Reich; DA Groneberg. J. Occup. Med. Toxicol., 2006, 1, 1-6.

[13] T Jin; M Nordberg; W Frech; X Dumont; A Bernard; TT Ye; Q Kong; Z Wang; P Li; NG Lundstrom; Y Li; GF Nordberg. Biometals, 2002, $15,397-410$ 